Є. Іванов. Передумови формування..

ISSN 2519-2620. Проблеми геоморфології і палеогеографії...2019. Вип. 1 (9), 49-61

УДК 913.1:912.43-134; DOI 10.30970/gpc.2019.1.2801

ПЕРЕДУМОВИ ФОРМУВАННЯ СУЧАСНИХ ЛАНДШАФТІВ МЕЖИРІЧЧЯ ЗАХІДНОГО БУГУ, РАТИ І СОЛОКІЇ (ЧастИНа 2)

Свген Іванов

Львівський наиіональний університет імені Івана Франка, eugen_ivanov@email.ua; orcid.org/0000-0001-6847-872X

Анотація. Розглянуто актуальні проблеми виникнення, формування, антропогенної трансформації та зникнення сучасних геосистем межиріччя Західного Бугу, Рати i Солокії. Особливу увагу присвячено дослідженню умов формування Яструбецької дельти як нехарактерної для регіону ділянки річкової долини Західного Бугу. На основі ретроспективно-географічного аналізу літературних і картографічних джерел XVIII$\mathrm{XX}$ ст. поетапно простежено умови розвитку геосистем Яструбецької дельти та оточуючих ландшафтів межиріччя.

У другій частині статті продовжено аналіз великомасштабних $(1: 25000)$ картографічних творів, зокрема дешифровано австрійські карти Третього топографічного знімання (1869-1887), польські карти Військового географічного інституту (1929-1939) і радянські карти Генерального штабу СРСР (1968-1989). Огляд топографічних карт останніх трьох 3 п'яти історико-географічних зрізів дав змогу дослідити та інтерпретувати умови функціонування і розвитку малополіських ландшафтів у другій половині XIX - другій половині XX ст. Для уточнення географічної і ландшафтноекологічної ситуації використано карти масштабу $1: 50000-1: 300000$.

Проаналізовано головні тенденції трансформації ландшафтів межиріччя Західного Бугу, Рати і Солокії за останні 240 років. Найкраще напрям перетворення природних умов відображають зміни у річковій мережі та залісненості і заболоченості території. Результати аналізу картографічних матеріалів засвідчують обміління і пересихання більшості русел і рукавів Західного Бугу та його приток, передусім у межах Яструбецької дельти, та суттєве скорочення заліснених і заболочених площ.

Ключові слова: ландшафт; геосистема; річкова долина; русло; дельта; межиріччя.

\title{
THE PRECONDITIONS OF MODERN LANDSCAPES FORMING BETWEEN WESTERN BUG, RATA AND SOLOKIA RIVERS (Part 2) \\ Eugen Ivanov
}

Ivan Franko National University of Lviv

Abstract. Actual problems of origin, formation, anthropogenic transformation and disappearance modern geosystems between Western Bug, Rata and Solokiya rivers are considered. Special attention devoted to formation conditions research of Yastrubetska Delta as uncharacteristic for region of the Western Bug river valley. Based on retrospective-geographic analysis of literature and cartographic sources of the XVIII-XX centuries are traced stages of the Yastrubetska delta geosystems development and surrounding landscapes of between-river basin.

In the second part of article analyzes the large-scale $(1: 25,000)$ cartographic works, in particular, the Austrian maps of the Third Topographic Survey (1869-1887), the Polish maps of the Military Geographical Institute (1929-1939) and the USSR Soviet General Staff maps (1968-1989).

An overview of last three of five historical and geographical stages topographic maps made it

(C) Іванов Свген, 2019. 


$$
\text { Є. Іванов. Передумови формування... }
$$

possible to investigate and interpret conditions of Small-Polissya landscapes functioning and development in second half of XIX-th - second half of XX-th centuries. Maps of scale $1: 50,000-1: 300,000$ used for clarifying geographical and landscape-ecological situation.

The main tendencies of Western Bug, Rata and Solokiya rivers interfluve landscapes transformation for the last 240 years was analyzed. The best indicator for natural conditions transformation are changes in river network, forestation and territory bogging. The analysis of cartographic materials shows that the majority of channels and distributaries of Western Bug and its tributaries, especially within limits of Yastrubetska Delta and a significant reduction of forested areas and wetlands.

Key words: landscape; geosystem; river valley; channel; delta; rivers interfluve.

Вступ. Пропонована стаття є завершенням опублікованої раніше праці (Іванов, 2018), що містить результати дослідження передумов формування частини річкової долини Західного Бугу, в історичних документах зазначеної як Яструбецька дельта, та оточуючих геосистем межиріччя Західного Бугу, Рати і Солокії.

Дешифрування австрійських карт Третього топографічного знімання (1869-1887). Карти цього топографічного знімання складено у процесі проведення третього кадастрового земельного опису за часів правління імператора Франца-Йосифа I (нім. Franzisco-Josephinische (Kuhn'sche) Kataster, Landesaufnahme). Після Йосифинської і Францисканської метрик, зазначене знімання стало третім проектом картографування Австро-Угорської імперії. Інколи, щоб не плутати із попередніми метриками, кадастровий опис називають на честь ініціатора його проведення - барона Франца Куна. Як і попередні метрики, його супроводжували топографічні карти, проте у масштабі $1: 25000$. Вони відзначаються вищою точністю вимірювання та, на відміну від попередніх, їх виконано у метричній системі. Порівняно з Другим топографічним зніманням, географічну ситуацію суттєво уточнено.

Попри значну частку заліснення і заболочення території, зникло чимало дрімонімів і гелонімів. Підписаною заболоченою ділянкою залишилося урочище Рочин. Водночас серед припіднятих еолових форм рельєфу змін у назвах топонімів фактично не відбулося, окрім урочища Гірки, яке, щоправда, картограф помилково позначив як Курки (Kurki). Яструбецьку дельту підписано великим написом БУГ (BUG Fl.). Інші підписи русел і рукавів річки відсутні. На листи карти нанесено три водяні млини у Новому Дворі, Пархачі і Сільці (останній зберігся донині).

Яструбецька дельта станом на сьогодні залишається заболоченою, однак у іiі центральній частині формуються зарослі верболозами сухіші ділянки, які регулярно затоплюють повеневі і паводкові води. У річковій мережі, порівняно 3 попереднім історичним зрізом, суттєвих змін не відбулося. Однак відбувалися зміни у співвідношенні між широкими повноводними і вузькими рукавами на користь перших та зникли окремі затони. Волсвинське русло і надалі відігравало важливу роль у функціонуванні водної системи Західного Бугу, однак Рата була ширшою і повноводнішою за Волсвинське і Городищенське русла. Район злиття цих русел 3 Ратою залишається практично незмінним протягом усього досліджуваного періоду, зміщення місць впадіння не перевищує 200-300 м. Доцільно наголосити на появі системи осушувальних каналів поблизу с. Поздимир у заболоченому водозборі безіменного потоку. 
Є. Іванов. Передумови формування...

ISSN 2519-2620. Проблеми геоморфології і палеогеографії...2019. Вип. 1 (9), 49-61

На картах Третього топографічного знімання якнайкраще відображено уступи першої і другої надзаплавних терас та схили еолових форм рельєфу (рис. 1). Помітна різниця між лівим і правим корінними берегами долини Західного Бугу.

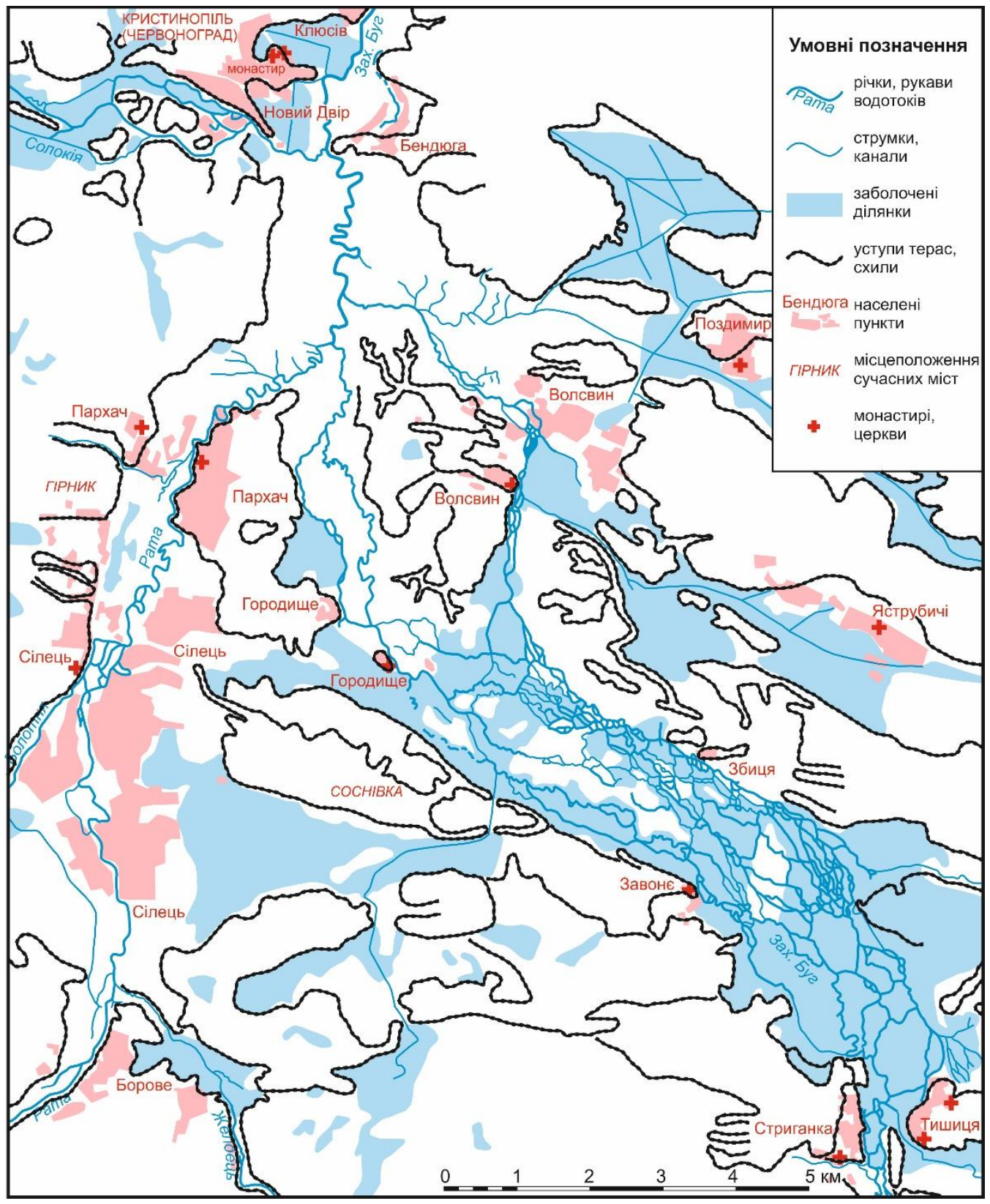

Рис. 1. Формування сучасних ландшафтів межиріччя Західного Бугу, Рати i

Солокії на основі дешифрування австрійських карт Третього топографічного знімання масштабу $1: 25000$ (карт метрики Франца Куна, 1869-1887рр.)

Fig. 1. Modern landscapes formation of Western Bug, Rata and Solokiya rivers interfluve based on Austrian maps of the Third Topographic Survey in scale $1: 25,000$ (Franz Kuhn metric maps, 1869-1887) decoding 
Є. Іванов. Передумови формування...

Уздовж більшої частини лівого берега сформовано чітку брівку першої надзаплавної тераси висотою 2-3 (до 5-ти) метрів, яка має декілька розмивів у місцях їхнього з'єднання 3 пониженими прадолинами. Доволі виразне таке з'єднання долин Західного Бугу і Рати помічаємо між Городищем і Сільцем. Правий берег не утворює єдиної брівки, його сильно розмило, а вздовж умовної межі спостерігаємо підняття-останці еолових форм рельєфу. Загалом перша надзаплавна тераса на правому березі Західного Бугу розмита, відчутна різниця між останцями палеодюн і пасм та пониженими заболоченими ділянками.

Дешифрування польських карт Військового географічного інститугу (1929-1939). За основу взято оригінальні топографічні карти масштабу $1: 25$ 000, що розроблені Військовим географічним інститутом протягом 1929-1939 рр. Ці картографічні твори відзначаються належною якістю і точністю, їх оновлено та стандартизовано інститутом на заміну старим німецьким, російським та австрійським топокартам.

Перед Другою світовою війною польською владою реалізовано комплекс гідротехнічних заходів зі спрямлення і заглиблення русла Західного Бугу. Метою цього масштабного проекту задекларовано осушення земельних угідь у межах Ястубецької дельти, освоєння заболоченої та перезволоженої місцевості. Після будівництва утворилося нове прямоточне крутосхиле русло довжиною 17 км, яке заглибили на 1,5-3,0 м щодо рівня попередніх русел і рукавів у дельті. На жаль, не вдалося відшукати документацію цього проекту, проте на основі аналізу тогочасних картографічних матеріалів можемо визначити орієнтовний період спрямлення і заглиблення русла. Зокрема, на топокарті масштабу $1: 25000$, виданій 1933 р., проект каналу ще не реалізовано, однак уже створено водовідвідний канал з метою перекидання повеневих вод із північно-східної частини Яструбецької дельти та від Волсвинського до Городищенського русла. Ймовірно, цей канал відводив надлишкові води під час будівництва головного каналізованого русла. За допомогою космознімків вдалося дешифрувати заглиблення фрагмента водовідвідного каналу.

Своєю чергою, на польській топографічній карті масштабу 1:100 000, виданій 1936 р. і створеній на основі опрацювання протягом 1935-1936 pp. детальніших топооснов, позначено спрямлене і на більшості власної протяжності заглиблене головне каналізоване русло Західного Бугу, тобто гідротехнічне будівництво, найімовірніше, виконали упродовж 1933-1935 років. Історикокультурними пам'ятками, пов'язаними з будівництвом і маркуванням каналу, які збереглися до наших днів, є чавунні стовпці на його березі, геодезичні репери (репери такого взірця використовували упродовж 1926-1936 pp., їх описано у праці (Zаја̨с, 2016). Завдяки останнім спостерігали за водністю річки і розвитком руслових процесів. Чимало жителів Соснівки помилково вважало їх прикордонними знаками, хоча кордону на цій ділянці річки ніколи не було.

Інша докорінна зміна на карті - нанесення залізничної лінії Кристинопіль Сапіжанка, прокладеної вздовж долини Західного Бугу - на топооснові масштабу $1: 25000$ сліди залізниці відсутні. Найімовірніше, це результат технічної неточності картографа, оскільки залізничну колію позначено на аркушах давніших польських топографічних карт масштабу $1: 300000$ (1924-1932). Однак між ними також існують невідповідності маршруту колії. Наприклад, на 
топооснові 1924 р. залізницю прокладено по заплаві Західного Бугу і вона двічі пересікає Городищенське русло. Спорудження цих об'єктів у міжвоєнний час невипадкове: воно мало військово-стратегічне значення. На основі інших джерел (www.sokal.lviv.ua) дізнаємося щодо будівництва залізниці російськими військами ще за часів Першої світової війни (1914-1915 рр.). Тогочасна залізнична дільниця, побудована нашвидкуруч за 52 доби, ймовірно, була тимчасовою, виконувала тактичні завдання із перекидання військ уздовж лінії фронту, отож після закінчення війни ії знищили або розібрали. Насипи цієї колії використано для відбудови залізниці поляками у 20-х роках минулого століття.

Загалом для району дослідження приклад будівництва військово-стратегічних залізниць тимчасового характеру непоодинокий. На початку Другої світової війни, на основі пакту Молотова-Ріббентропа, сфери впливу між Радянським Союзом і Німеччиною поділили вздовж річок Солокія і Західний Буг, отож район знову виявився прикордонним. Спорудження укріплених районів лінії Молотова 1940-1941 рр. супроводжувало будівництво мережі залізничних вузькоколійок. На серії німецьких карт масштабу $1: 100000$ (1940-1944), створеної відповідно до об'єднаних аркушів польських карт, нанесено бункери, смуги заслону та оборони та інші військові об'єкти лінії Молотова. Вузловим залізничним пунктом для спорудження Рава-Руського укріпленого району стала станція Сілець-Завонє (тепер Соснівка), від якої відходили дві гілки вузькоколійок. Північна гілка пересікала долину Західного Бугу і проходила через Городище, Волсвин і Бендюгу до лісу маєтку Поториця (Las majatku Potorzyca). Упродовж 1960-1980-х років цей великий лісовий масив неподалік Червонограда використовували для створення військової бази ракетних військ стратегічного призначення. На вузькоколійці існували мостові переходи через Городищенське і Волсвинське русла, залишки дерев'яних опор та насипу першого 3 них збереглися досі. Прикладом іншої прикордонної залізничної ділянки у межиріччі Західного Бугу і Рати є колія Старий Добротвір - Реклинець - Рава-Руська, що діяла у повоєнні часи і насипи якої збереглися у задовільному стані.

Відзначимо інформативність польської карти, насиченої географічними назвами. Здебільшого топоніми збережено 3 часів панування Австрійської імперії, при цьому використано назви географічних об'єктів 3 карт Другого і Третього топографічного знімання. До них у межиріччі Західного Бугу і Рати додано тогочасні дрімоніми: Острівок (Ostrywok), У лісі (Wlisi), На соснах ( $\mathrm{Na}$ sosnach), За ставком (Za stawkiem) та ін. Нові топоніми з'явилися в межах Яструбецької дельти, такі як На гострому (Na ostrum) і Маковисько (Makawiska). Найвищу щільність заселення спостерігаємо у долині Рати, де розростаються села Сілець і Пархач. Ці території, поряд із районом сіл Поздимир і Яструбичі, добре освоєні та використані у сільському господарстві. Водночас під час Другої світової війни 1944 року німецькі війська спалили с. Завонє, а після її завершення спустошили присілки Збиця і Козак. Зниклі поселення знаходилися в межах піднять-островів Яструбецької дельти, що спричинило занепад його осушених, однак малородючих площ.

Розглянемо ландшафтно-екологічну ситуацію, яка сформувалася перед початком будівництва каналізованого русла Західного Бугу (рис. 2). Порівняння 3 австрійськими картами Третього топографічного періоду дає змогу виявити скорочення кількості русел і рукавів та ознаки їхнього замулення у нижній 
частині Яструбецької дельти. Ї̈ верхня частина залишилася практично незміненою, водночас у нижній частині дельти зменшилися площі заболочених і перезволожених земель. Також існує тенденція до зміщення повноводних водотоків

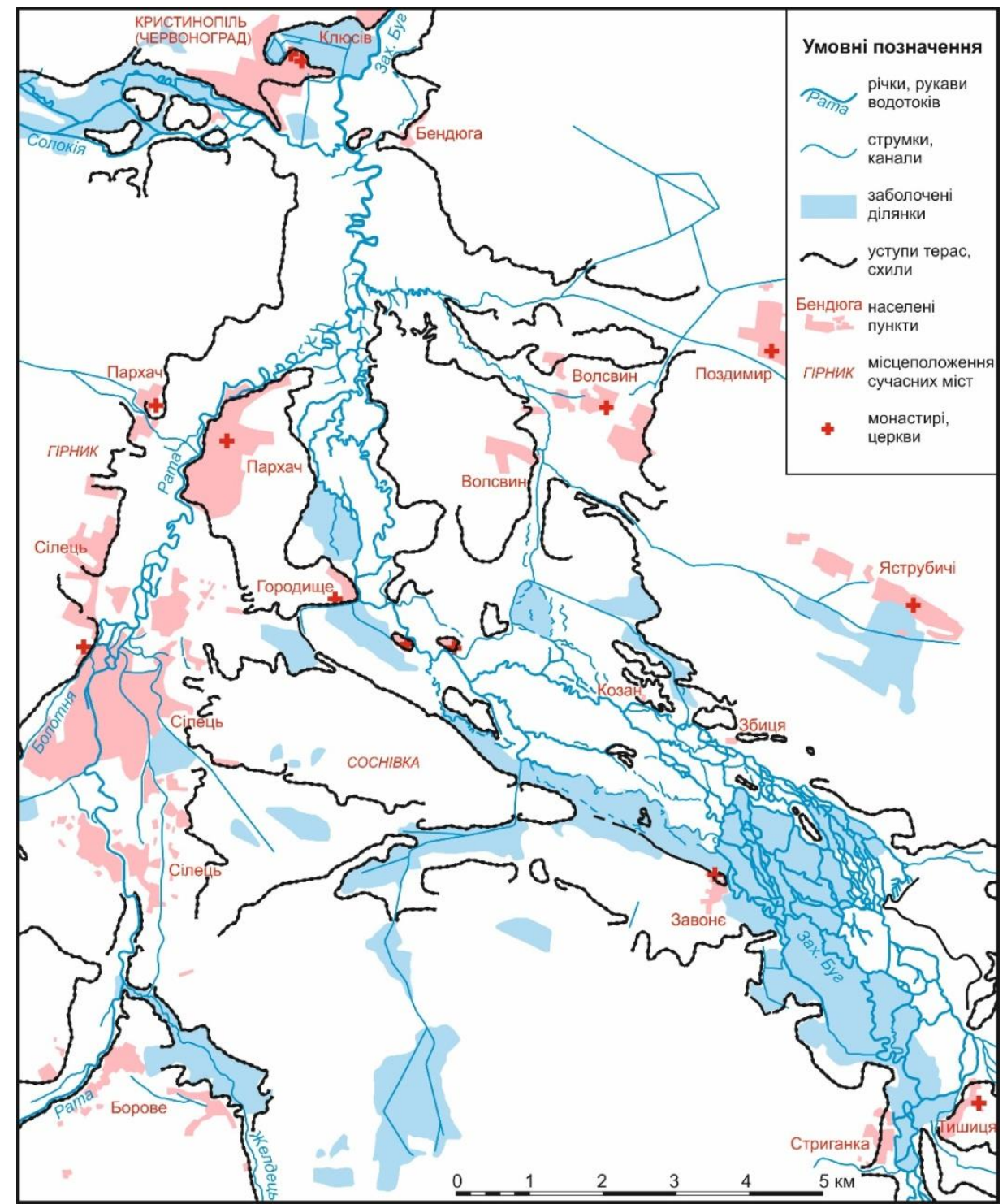

Рис. 2. Формування сучасних ландшафтів межиріччя Західного Бугу, Рати і Солокії на основі дешифрування польських карт Військового географічного інституту (WIG) масштабу $1: 25000$ (1929-1939 pp.)

Fig. 2. Modern landscapes formation of Western Bug, Rata and Solokiya rivers interfluve based on polish maps of Military Geographical Institute (WIG) in scale $1: 25000$ (1929-1939 years) decoding

дельти у північно-східному напрямі. Волсвинське русло існує досі, хоча втрачає розгалуженість і стає мілководнішим. Скидання водовідвідним каналом води у 
Городищенське русло остаточно перетворює його в головне річище Західного Бугу.

Будівництву головного каналізованого русла Західного Бугу передували водовідвідні роботи на його малих притоках для осушення оточуючих лісових масивів. 3 метою запобігання підтопленню забудови й угідь у Сільці (проблеми iз затопленням і підтопленням села існували до початку видобування кам'яного вугілля і просідання земної поверхні) проведено спрямлення русла та інші водовідвідні роботи у долині Рати. Окремий канал відводив надлишкові води із заболоченого урочища Рочин, що сприяло його осушенню. Отже, ще перед спрямленням русла Західного Бугу площі під заболоченими землями зменшилися. Наприклад, від часу експлуатації осушувальної мережі у районі с. Поздимир землі перестали бути заболоченими і перезволоженими.

Одразу після спрямлення і заглиблення головного русла Західного Бугу бічні підняті й перегороджені у верхній частині русла і рукави, здебільшого, пересихають або замулюються. Нижні подовжені (понад 2-3 км) і часом спрямлені частини рукавів є заводненими і слугують для відведення поверхневих вод у річку. Довкола каналізованого русла залишилися сухі меандрові пониження річки. Волсвинське русло втрачає пряме з'єднання з головним річищем і перетворюється у локальний водозбір, яким стікають води старих рукавів і малих приток Західного Бугу.

Дешифрування радянських карт Генерального штабу СРСР (1968-1989). Незважаючи на те, що фактично усю територію Радянського Союзу відображено на топографічних картах масштабу $1: 25$ 000, інформацію приховували від населення та навмисно спотворювали картографічне зображення. Радянські карти повоєнного періоду мали нижчу від попередніх топографічних знімань інформативність, маскуючи чимало географічних об'єктів. Серед топонімів на карті позначені лише великі лісові масиви, такі як Рочин і Потужиця (залишено написання з польської топокарти, оригінальна назва Поториця).

Побудоване понад 50 років тому головне каналізоване русло Західного Бугу практично не зазнало змін. Після запуску Добротвірської ДРЕС 1955 р. в межах каналу прискорилася швидкість течії, що сприяло його поглибленню. Ширина русла становить 25-30 м, а глибина - 1,5-1,6 м. Незважаючи на те, що Волсвинське русло на радянській карті показано з'єднаним з головним руслом, ставимо під сумнів його дієвість (вірогідно таке лише під час повеней і паводків). Існування цього з'єднання не підтверджено спогадами місцевого населення. Здебільшого малі потоки каналізовано, розширено мережу каналів, що спричинило подальше осушення заболочених і перезволожених територій. Південніше Соснівки спостерігаємо біфуркацію водотоків, чому сприяє плоский понижений характер прадолини Західного Бугу.

Головною відмінністю від попередніх топокарт є поява вуглевидобувних і вуглезбагачувальних підприємств Львівсько-Волинського басейну. Перші вугільні шахти здано в експлуатацію упродовж 1958-1961 pp. Мережу гірничопромислових об'єктів (шахт, відвалів, відстійників тощо) закладено практично повністю. Антропогенне навантаження на ландшафти межиріччя Західного Бугу, Рати і Солокії зростає, проте ще максимально не проявилося. Наслідки трансформації природно-господарських систем швидше окреслилися у районі Червонограда, де знаходяться найстаріші вугільні шахти однойменного 
гірничопромислового району. Рівень антропогенного пресингу на ландшафти спадає у напрямі до Соснівки, де він зріс 1979 р., після введення в експлуатацію Червоноградської иентральної збагачувальної фабрики (ЦЗФ). Зазначимо, що невдало обрали місце для будівництва фабрики проектанти. Межиріччя Західного Бугу і Рати обмежило його просторовий розвиток, а інтенсивне розроблення кам'яного вугілля шахтами посилило спектр геоекологічних проблем у густозаселеному районі. Не враховано також домінування західного переносу повітряних мас і винесення геохімічного забруднення безпосередньо на Соснівку, яка розміщена в 1 км від головних його джерел.

На заплавних поверхнях Західного Бугу і Рати побудовано гідротехнічні споруди - хвостосховища, відстійники і стави-накопичувачі шахтних вод. Найбільшими 3 них є об'єкти ЦЗФ (рис. 3). На карті зображено дамби і секції намивання хвостосховища № 1 (так званого старого, 72 га) і ставів-накопичувачів шахтних і технологічних вод (63 га). Побудовані споруди суттєво трансформували гідрогеологічні умови довкола них, змінили та сповільнили поверхневий і підземний стік, спричинили підтоплення і заболочення оточуючих територій.

Затоплені і підтоплені площі з'явилися на заплаві Західного Бугу. На карті зображено водойми, що виникли внаслідок затоплення площ у межах шахтних полів шахт № 1, 2 і 3 "Великомостівські” і № 1 "Червоноградська". Тобто затоплені і заболочені ділянки сформувалися, здебільшого, нижче від злиття Західного Бугу і Рати, неподалік Червонограда. Окремі затоплені фрагменти зафіксовано на першій надзаплавній терасі. Найбільші дві зони затоплення (2530 га) нанесено у районі с. Городище, поряд зі ставами-накопичувачами ЦЗФ. Одну із цих зон затоплення прорізає русло річки, у цьому місці формується епіцентр депресійної лійки із просіданнями земної поверхні до 1,5-3,0 м.

Відзначимо подальше зменшення заболочених площ у межах Яструбецької дельти. Завершився процес обміління і зневоднення значної кількості малих рукавів і залишилося шість-сім основних русел, які продовжують дренувати дельту. Одне з найдовших і сильнозвивистих русел у місцевих отримало назву Старого Бугу. Це заболочене річище із берегами, зарослими деревами $\mathrm{i}$ чагарниками, й сьогодні відмінно зберіглося. Поряд із шахтою № 2 "Великомостівська" чітко виокремлені інші сильнозвивисті стариці у сосновому лісі, які позначено ще на австрійських картах Другого топографічного знімання. Посилення візуалізації їхніх обрисів зумовлено просіданням і заводненням пересохлих русел. Загалом закріплені деревами піщанисті схили старичних русел дали змогу останнім зберігатися у задовільному стані понад 200 років. Сьогодні найдовшу старицю пересікає молодий безіменний потік.

Будівництво вугільних шахт і вуглезбагачувальних фабрик супроводжувало спорудження розгалуженої мережі залізниць і комунікацій. До кожної шахти підведено залізничні колії, що порушують поверхневий стік води і посилюють підтоплення та заболочення територій. Одна із залізничних гілок пересікає долину Західного Бугу, однак в іншому місці ніж передвоєнна залізниця часів спорудження укріпленого району лінії Молотова. Для цього побудовано новий суміщений залізнично-автомобільний міст. Колія, що обслуговувала шахти № $2 \mathrm{i}$ 5 “Великомостівські”, після їхньої ліквідації закинута і фрагментарно заросла.

Аналіз тенденцій зміни природних умов. На завершення проаналізуємо головні тенденції трансформації ландшафтів межиріччя Західного Бугу, Рати i 


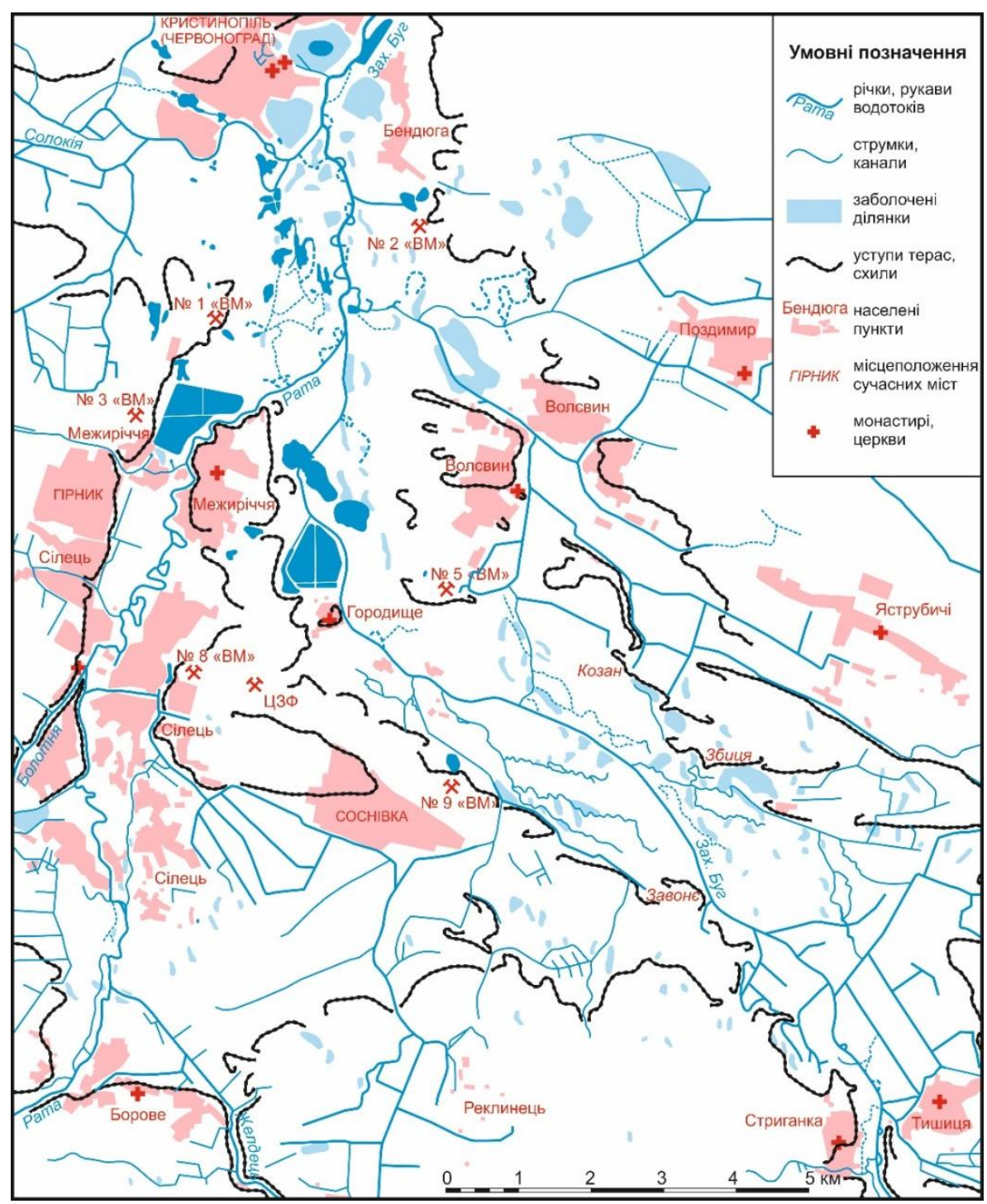

Рис. 3. Формування сучасних ландшафтів межиріччя Західного Бугу, Рати і

Солокії на основі дешифрування радянських карт Генерального штабу СРСР масштабів 1 : 25000 і 1 : 50000 (1968-1989 pp.)

Fig. 3. Modern landscapes formation of Western Bug, Rata and Solokiya rivers interfluve based on USSR Soviet General Staff maps in scales $1: 25000$ and $1: 50000$ (1968-1989 pp.) decoding

Солокії за останні 240 років. Найкраще напрям перетворення природних умов у районі дослідження відображають зміни у річковій мережі. Під час дешифрування різночасових топографічних карт детально опрацьована мережа річок, потічків і каналів із виокремленням головних і другорядних (шириною до 3 м) водотоків. Зважаючи на розгалуженість річкової мережі, оцифрування водотоків здійснено окремими ділянками (відтинками) між рукавами, каналами і старицями, що сприятиме зручності їхнього подальшого обліку. Обрахування 
кількості водотоків проведено для п'яти історичних періодів у розрізі цілого району дослідження та окремо в межах Яструбецької дельти.

Результати аналізу картографічних матеріалів XVIII-XX ст. засвідчують повільне обміління і пересихання більшості русел і рукавів Західного Бугу та його приток (табл. 1). Однак цей процес розпочався ще до будівництва головного каналізованого русла Західного Бугу. Найбільшу кількість водотоків (451 од.) обраховано на австрійських топокартах Другого топографічного знімання, проте найбільше головних повноводних водотоків (298 од.) обліковано на старіших

Таблиця 1. Динаміка зміни річкової мережі в межах межиріччя Західного Бугу, Рати і Солокії

Table 1. River network changes dynamics within Western Bug, Rata and Solokiya rivers interfluve

\begin{tabular}{|c|c|c|c|c|c|}
\hline Параметри водотоків & $\begin{array}{l}\tilde{\Xi} \\
0 \\
0 \\
0 \\
0 \\
0 \\
0 \\
0 \\
0 \\
0 \\
0\end{array}$ & 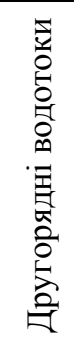 & $\begin{array}{l}\Sigma \\
0 \\
\tilde{y} \\
\tilde{O}\end{array}$ & 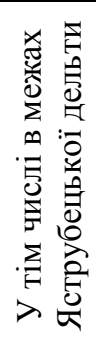 & 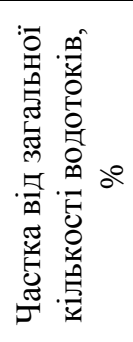 \\
\hline $\begin{array}{l}\text { Австрійські карти Першого } \\
\text { топографічного знімання (1779-1783) }\end{array}$ & 298 & 85 & 383 & 248 & 64,8 \\
\hline $\begin{array}{l}\text { Австрійські карти Другого } \\
\text { топографічного знімання (1819-1820) }\end{array}$ & 143 & 308 & 451 & 285 & 63,2 \\
\hline $\begin{array}{l}\text { Австрійські карти Третього } \\
\text { топографічного знімання (1869-1887) }\end{array}$ & 196 & 136 & 342 & 227 & 66,8 \\
\hline $\begin{array}{l}\text { Польські карти Військового } \\
\text { географічного інституту (1929-1939) }\end{array}$ & 172 & 168 & 340 & 211 & 62,1 \\
\hline $\begin{array}{l}\text { Радянські карти Генерального штабу } \\
\text { СРСР (1968-1989) }\end{array}$ & 108 & 139 & 247 & 62 & 25,1 \\
\hline
\end{tabular}

топокартах. Найімовірніше, специфіка картування у другій половині XVIII ст. не давала змоги нанести окремі другорядні водотоки, тогочасна кількість яких була значно більшою. Осушувальна меліорація не змогла суттєво вплинути на скорочення водотоків у районі дослідження. Загальна кількість водотоків зменшилася фактично вдвічі і сьогодні становить 54,8 \% від їхньої максимальної кількості.

Розглянемо детальніше особливості гідроекологічної ситуації в межах Яструбецької дельти. До будівництва головного каналізованого каналу тут було зосереджено 62,1-66,8 \% водотоків району дослідження. Щонайбільше вдалося облікувати 285 рукавів Західного Бугу (рис. 4). Після цього кількість водотоків поступово зменшувалася і перед Другою світовою війною становила 211 водних об’єктів. Сьогодні кількість водотоків у Яструбецькій дельті суттєво скоротилася - до 62 водних об'єктів, більшість 3 яких є затонами і старицями. Швидке зменшення водотоків у дельті випереджає тенденції щодо їхнього загального 
скорочення, отож сьогодні тут нараховують лише 25,1 \% водних об'єктів району дослідження.

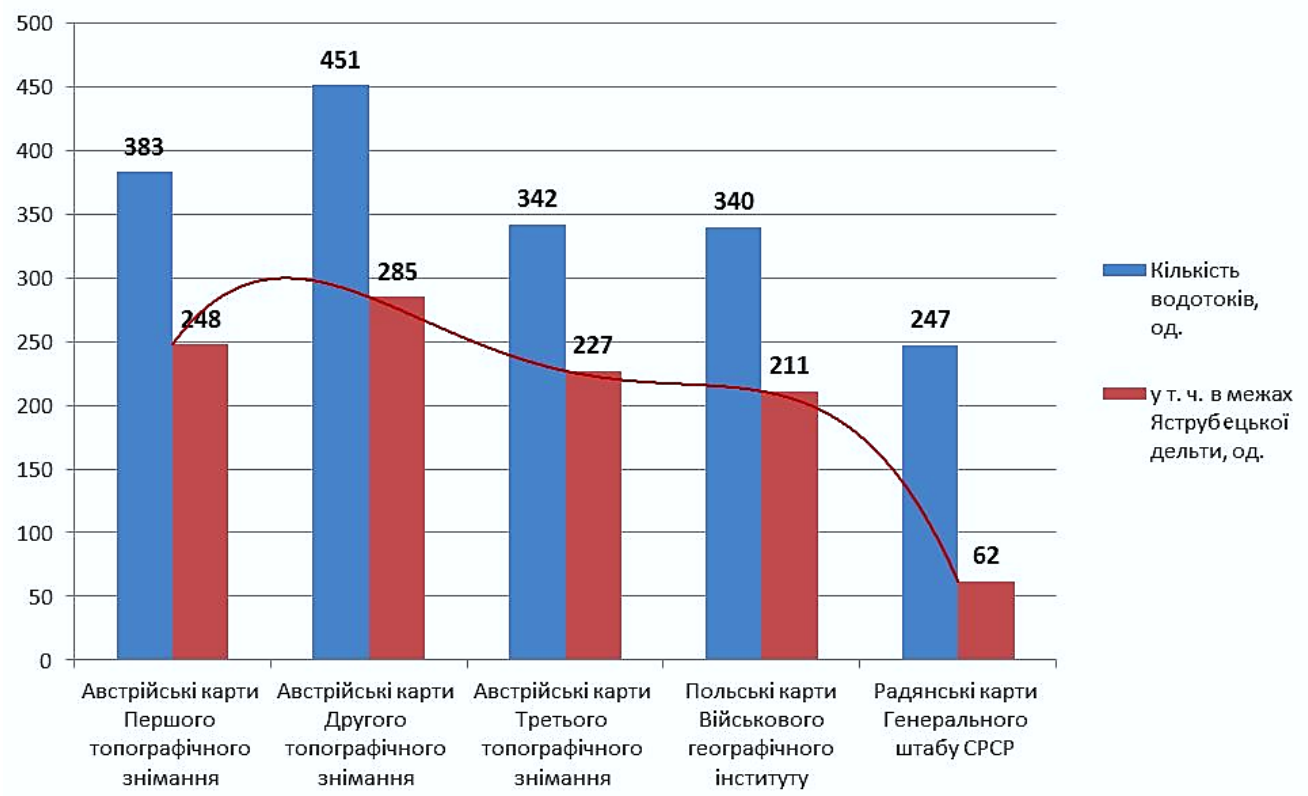

Рис. 4. Динаміка зміни річкової мережі в межах межиріччя Західного Бугу, Рати і Солокії

Fig. 4. River network changes dynamics within Western Bug, Rata and Solokiya rivers interfluve

Важливими показниками трансформації природного середовища у районі дослідження вважаємо частки залісненості і заболоченості території. Контури площ лісів і боліт за останні 240 років неодноразово змінювалися. Відзначимо загальні тенденції до зменшення заліснених і заболочених площ, однак процес їхнього скорочення відбувався по-різному.

Історично соснові, дубово-соснові і заплавні ліси у межиріччі Західного Бугу, Рати і Солокії домінували над іншими земельними угіддями. Поступове освоєння малородючих і перезволожених малополіських земель спричинило зменшення лісових масивів, яке відбувалося рівномірно і відносно повільно. У 1780-х роках показник залісненості становив $62,9 \%$, у 1880 -х роках $-49,7 \%$, у 1980 -х роках 37,2 \% від загальної площі району дослідження. Попри істотне скорочення лісових угідь, лісистість залишилася високою $\mathrm{i}$ перевищує загальний регіональний $(28,5 \%)$ показник.

Здебільшого заболочені і перезволожені площі трапляються у долинах Західного Бугу і Солокії, а також у межах їхніх дрібних і малодіяльних приток. Аналіз різночасових топокарт вказує на регулярні зміни розміщення заболочених ділянок, передусім у межах Яструбецької дельти. До спорудження головного каналізованого русла Західного Бугу, спрямлення русел Рати і Солокії та осушувальних робіт на малих водотоках показник заболоченості залишався високим i коливався у межах 14,6-23,1\%. Чимало заболочених площ знаходилося у великих лісових масивах. Після завершення комплексу русло- 
спрямлювальних та осушувальних робіт частка заболоченості впала до 7,8 \% від загальної площі району дослідження. Найімовірніше, ця частка була б нижчою, проте обчислення площ заболочених і перезволожених ділянок зроблено на основі радянських карт 1970-1980-х років, на які нанесено тогочасні зони затоплення і підтоплення, утворені внаслідок експлуатації вугільних шахт і ЦЗФ.

У формуванні сучасних ландшафтів межиріччя Західного Бугу, Рати і Солокії важливу роль відіграли новітні тектонічні рухи. Інтенсивність тектонічних рухів встановлюють за геоморфологічними ознаками i, зокрема, за результатами вивчення змін річкових заплав i терас. Дешифрування топокарт дало змогу визначити тенденції прояву неотектонічних рухів. Свідченням тектонічної активності досліджуваної території є землетрус із епіцентром у районі с. Сілець, який відбувся 17 вересня 1875 р. Сила землетрусу становила 6 балів за шкалою MSK-64 (Бень, Волошин і Назаровець, 2004). Сучасна геодинамічна активність та неотектонічні рухи підтверджують високу ймовірність повторного землетрусу у регіоні.

Висновки. Окреслені тенденції змін природних умов району дослідження дають змогу сформулювати такі головні підсумки:

1. Межиріччя Західного Бугу, Рати і Солокії відзначає складна тектонічна структура, геологічна і геоморфологічна будова, що вплинули на формування сучасних ландшафтів. На основі історичних літературних і картографічних джерел вдалося відстежити активні перетворення геосистем долин цих водотоків за останні 240 років, інтерпретувати ймовірні напрями стоку поверхневих вод і домінуючих повітряних потоків у післяльодовиковий період.

2. Яструбецька дельта, як частина долини Західного Бугу між Стриганкою i Червоноградом, є динамічним гідрологічним утворенням, яке зазнає постійних природних та антропогенних “потрясінь”. Інтенсивність руслових процесів, нестійкість піщаних відкладів та активні неотектонічні рухи неодноразово перетворювали рисунок дельти. Дешифрування різночасових топографічних карт дало змогу окреслити тенденції зміни щільності рукавів і заболочених ділянок, визначити чинники іiі трансформації і фактичного зникнення.

3. Критична екологічна ситуація в межах Червоноградського гірничопромислового району значною мірою спричинена умовами формування сучасних малополіських ландшафтів, складними трансформаційними змінами заплавних i надзаплавних геосистем межиріччя Західного Бугу, Рати і Солокії. Це необхідно враховувати у процесі розроблення оптимізаційних заходів щодо покращення екологічного стану природного середовища району дослідження.

\section{СПИСОК ВИКОРИСТАНОЇ ЛІТЕРАТУРИ}

Бень Я., Волошин І., Назаровець І. Особливості геопатогенних зон динамічно активних територій та захворювань населення // Вісн. Львів. ун-ту. Сер. геогр. -2004. - Вип. 30. - С. 331-338.

Іванов $€$. Передумови формування сучасних ландшафтів межиріччя Західного Бугу, Рати і Солокії (Частина 1) // Проблеми геоморфології і палеогеографії Українських Карпат і прилеглих територій. - 2018. - Вип. 1 (8). - С. 171-184. 
Habsburg Empire (1869-1887). Third Military Survey (1 : 25 000). Режим доступу : https://mapire.eu/en/map/thirdsurvey25000/

Mapa Szczegolowa Polski 1 : 25000 (1929-1939). Режим доступу : http://igrek. amzp.pl/mapindex.php?cat=WIG25

Zając D. Tajemnicze żeliwne słupki w dolinie Wisłoki [електрон. pecypc]. Режим доступу : http://www.beskid-niski-pogorze.pl/artykuly/tajemnicze_slupki.php.

\section{REFERENCES}

Ben, Ya., Voloshyn, I., Nazarovets, I. (2004) Osoblyvosti heopatohennykh zon dynamichno aktyvnykh terytorii ta zakhvoriuvan naselennia. In Visn. Lviv. un-tu. Ser. heohr., 30, 331-338. (in Ukrainian).

Ivanov, Ye. (2018) Peredumovy formuvannia suchasnykh landshaftiv mezhyrichchia Zakhidnoho Buhu, Raty i Solokii (Chastyna 1). In Problemy heomorfolohii $i$ paleoheohrafii Ukrainskykh Karpat i prylehlykh terytorii, 1 (8), 171-184. (in Ukrainian).

Habsburg Empire (1869-1887). Third Military Survey (1 : 25000). Retrieved from https://mapire.eu/ en/map/thirdsurvey25000/.

Mapa Szczegolowa Polski 1 : 25000 (1929-1939). Retrieved from http://igrek.amzp.pl/mapindex. php?cat=WIG25 (in Polish).

Zając, D. (2017) Tajemnicze żeliwne słupki w dolinie Wisłoki. Retrieved from http://www.beskid-niski-pogorze.pl/artykuly/tajemnicze_slupki.php (in Polish). 